Електронне наукове фахове видання "Ефективна економіка" включено до переліку наукових фахових видань України з питань економіки (Наказ Міністерства освіти і науки України від 11.07.2019 № 975) www. economy.nayka.com. ua | № 11, 2019 | 28.11.2019 p.

DOI: $\underline{10.32702 / 2307-2105-2019.11 .58}$

УДК:336.763.078.3(477):005.2

О. I. Мельник,

к. е. н, асистент кафедри економіки підприємства та управління персоналом,

Чернівецький національний університет ім. Ю. Федьковича,

ORCID: 0000-0002-0296-5426

I. M. Kanimaн,

дослідник кафедри економіки підприємства та управління персоналом,

Чернівецький національний університет ім. Ю. Федьковича,

ORCID: 0000-0002-5024-3015

\title{
СУЧАСНІ ТЕНДЕНЦІї РОЗВИТКУ ФОНДОВОГО РИНКУ УКРАЇНИ
}

\author{
O. I. Melnyk \\ PhD, assistant, Economy faculty \\ Yurii Fedkovich Chernivtsi National University \\ I. M. Kapitan \\ Researcher, Economy faculty \\ Yurii Fedkovich Chernivtsi National University
}

\section{MODERN TRENDS OF STOCK MARKET DEVELOPMENT IN UKRAINE}

У даній статті висвітлені сучасні тенденції розвитку фондового ринку України. Проведено аналіз сучасного стану фондового ринку України та здійснено порівняння за показником капіталізащії найбільших бірж світу та українських бірж. Було з'ясовано, щуо фондовий ринок краӥни має багато недоліків та потребує активних змін. У роботі виділені чотири основні проблеми розвитку фондового ринку Украӥни та представлені можливі шляхи їх вирішення. Першою проблемою є законодавча неврегульованість питань корпоративного урядування в акціонерних товариствах. 3'ясовано, щуо можливим рішенням цієї проблеми $\epsilon$ забезпечення захисту прав інвесторів, також представлені імовірні шляхи його досягнення. Друга проблема стосується організації фондового ринку України, а саме тривалості існування головного регулятора ринку ичінних паперів - Національної комісії з цінних паперів та фондового ринку. Доведено, щуо ї̈ вирімення потребує активізації впровадження необхідних законодавчих норм, розширення повноважень та приведення Комісії до вимог міжнародних стандартів. Третьою проблемою украӥнського фондового ринку є формування депозитарно-клірингової інфраструктури. В роботі проведений аналіз перших кроків державної влади на шляху ї̈ вирішення. Також у роботі обтрунтовано, щзо четвертою, $i$ найгострішою сучасною проблемою розвитку фондового ринку Украӥни є несвоєчасність, необтрунтованість та часто недостовірність інформації про діяльність учасників фондового ринку Украӥни. У статті висвітлена важливість інформаційних технологій та діджиталізачї̈ у сучасному світі і їх вплив на зростання економіки краӥни і фондового ринку, як індикатора розвитку, зокрема. Проведено детальний аналіз проблем та запропоновані шляхи покращення інформаційного забезпечення учасників фондового ринку Украйни. 
This article highlights current trends in the Stock market of Ukraine. The analysis of the current state of the Stock market of Ukraine has been done and a comparison has been made in terms of capitalization of the largest Stock Exchanges in the world and Ukrainian exchanges. It has been found that the Stock Market of the country has many bottlenecks and requires necessary changes. The paper identifies four main problems of development of the Stock market of Ukraine and presents possible solutions. The first problem is the non-effective legislative regulation of corporate governance issues in joint-stock companies. It is found that a possible solution to this problem is the investor rights protections. The likely ways of its solving are presented. The second problem concerns the organization of the stock market of Ukraine, namely the duration of existence of the main regulator of the securities market - the National Commission on Securities and Stock Market. It is proved that as soon as possible introduction of necessary legislative norms, and extension of powers and bringing of the Commission to the requirements of international standards are needed. The third problem of the Ukrainian Stock Market is the formation of depository and clearing infrastructure. The analysis of the first steps of the government for its solution has been done. It is also highlighted that the fourth and most acute current problem of the Stock market of Ukraine development is the untimely, unjustified and often unreliable information about the activities of the Stock Market participants in Ukraine. The article presents the importance of information technologies in the modern world and their impact on the growth of the country's economy and the Stock Market as an indicator of development, in particular. There are many reasons to expect that a country's investment in information communication technologies could result in improved economic growth. A detailed analysis of the problems and ways to improve the information support of Ukrainian stock market participants has been conducted. Solving the last problem can lead to sustainable improvement of Stock Market activities in Ukraine.

Ключові слова: фондовий ринок; капіталізація; законодавче регулювання; комісія з ичінних паперів та фондового ринку; інформаційне забезпечення.

Key words: stock market; capitalization; corporate governance; Commission on Securities and Stock Market; information technologies.

Постановка проблеми. На сучасному етапі розвитку світових економік одну з найважливіших ролей відіграє фондовий ринок, який відбиває рівень розвитку економіки країни загалом. Фондовий ринок України почав формуватися тільки після отримання незалежності, тому він ще є досить молодим і має багато слабких місць та проблем. У порівнянні зі світовими фондовими ринками, він $є$ слаборозвиненим, але здійснення необхідного комплексу заходів може не лише забезпечити його становлення, але й суттєво вплинути на темпи його розвитку. Ураховуючи наведені аргументи, дослідження сучасних тенденцій і виявлення проблем функціонування фондового ринку України є доволі своєчасним й актуальним.

Аналіз останніх досліджень та публікацій. Вивченням напрямів розвитку світового фондового ринку, а також національних фондових ринків займалося багато як іноземних, так і вітчизняних науковців. До вітчизняних вчених, які досліджували цю проблему можна віднести: Залюбовську С.С., Кравець А.В., Колупаєва Ю.Б., Мозговий О.М, Яковенко М.А. а ін. До зарубіжних науковців, які висвітлювали дану проблему у свої роботах належать: Альфорд М., Кресон Дж., Лі С., Сепергдуст Х. та ін.

Формулювання цілей статті. Метою статті $є$ висвітлення основних тенденцій, проблем, напрямів розвитку фондового ринку України та запропонувати можливі шляхи їх вирішення.

Виклад основного матеріалу. У сучасних умовах фондовий ринок України все ще можна вважати таким, який розвивається. Не зважаючи на певні зрушення у розвитку національного фондового ринку як у операціях, так і у регулятивній діяльності, український ринок все ще має багато проблем та недоліків.

Фондовий ринок в тій чи іншій країні може характеризуватися, в першу чергу, показниками капіталізації, обсягом біржової торгівлі цінними паперами, кількістю цінних паперів, що перебувають в обігу на фондових біржах та ін.

Обсяг ринкової капіталізації підприємств, що знаходяться в лістингу українських бірж значно поступається іншим країнам. Показник капіталізації емітентів, акції яких внесено до біржового реєстру станом на 01.01.2018, становив 7,97 млрд. грн. (288 млн. дол. США) [8]. Для порівняння, ринкова капіталізація тільки однієї Нью-Йоркської фондової біржі на той же час склала більше 23 трлн дол. США, що перевищує обсяг капіталізації всіх бірж України разом взятих майже у 80 тис. разів. А Варшавська фондова біржа, яка 
вважається найкращою у Східній та Центральній Європі, має капіталізацію у обсязі 162 млрд. дол. США, i знаходиться на 31 місці за капіталізацією у світі.

Для кращого розуміння місця українських бірж на світовому фондовому ринку, на рис. 1 представлені рівні капіталізації 10 найбільших бірж світу у порівнянні із капіталізацією сукупності усіх бірж України.

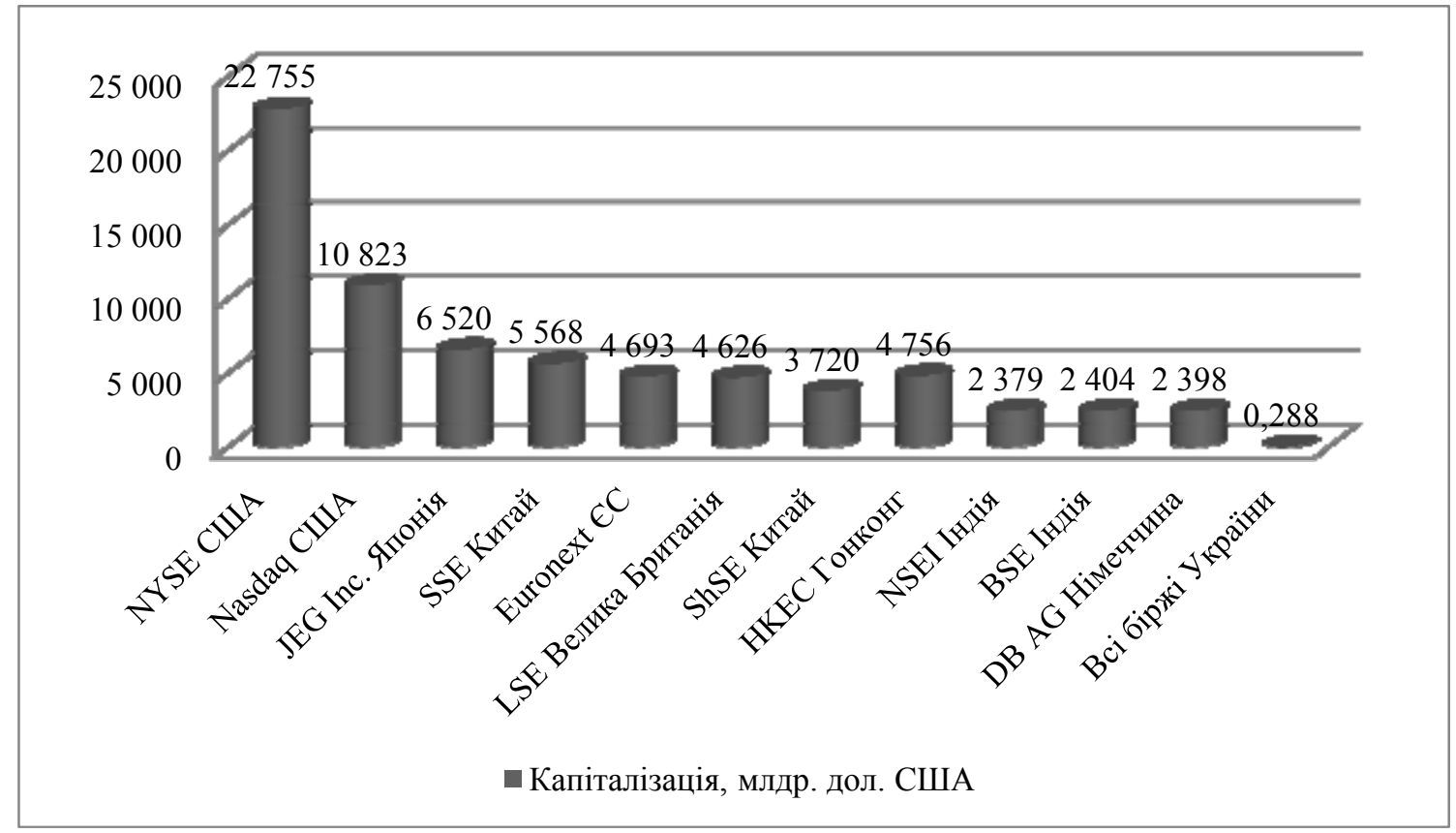

Рис. 1. Найбільші біржі за рівнем капіталізації станом на 31.12 .2018 року Примітка. Сформовано автором на основі [7]

За 2013-2018 роки в Україні спостерігається зменшення обсягів капіталізації, яке значною мірою пов'язане із зменшенням кількості випусків акцій, внесених до біржового реєстру як такі, що відповідають вимогам лістингу [8]. Дана тенденція негативно впливає на рівень розвитку фондового ринку у цілому.

За даними Національної комісії з цінних паперів та фондового ринку (НКЦПФР) у 2018 році, порівняно з 2017 роком, темп приросту обсягів торгів на ринку цінних паперів становив 26\% при зростанні ВВП на $3,2 \%$. Співвідношення обсягів торгів на ринку цінних паперів до ВВП - 19,8\%. За підсумками 2018 року спостерігалося зростання обсягу торгів на ринку цінних паперів, порівняно з 2017 роком, на 26\% - до 590,59 млрд. грн. (рис.2) [8].

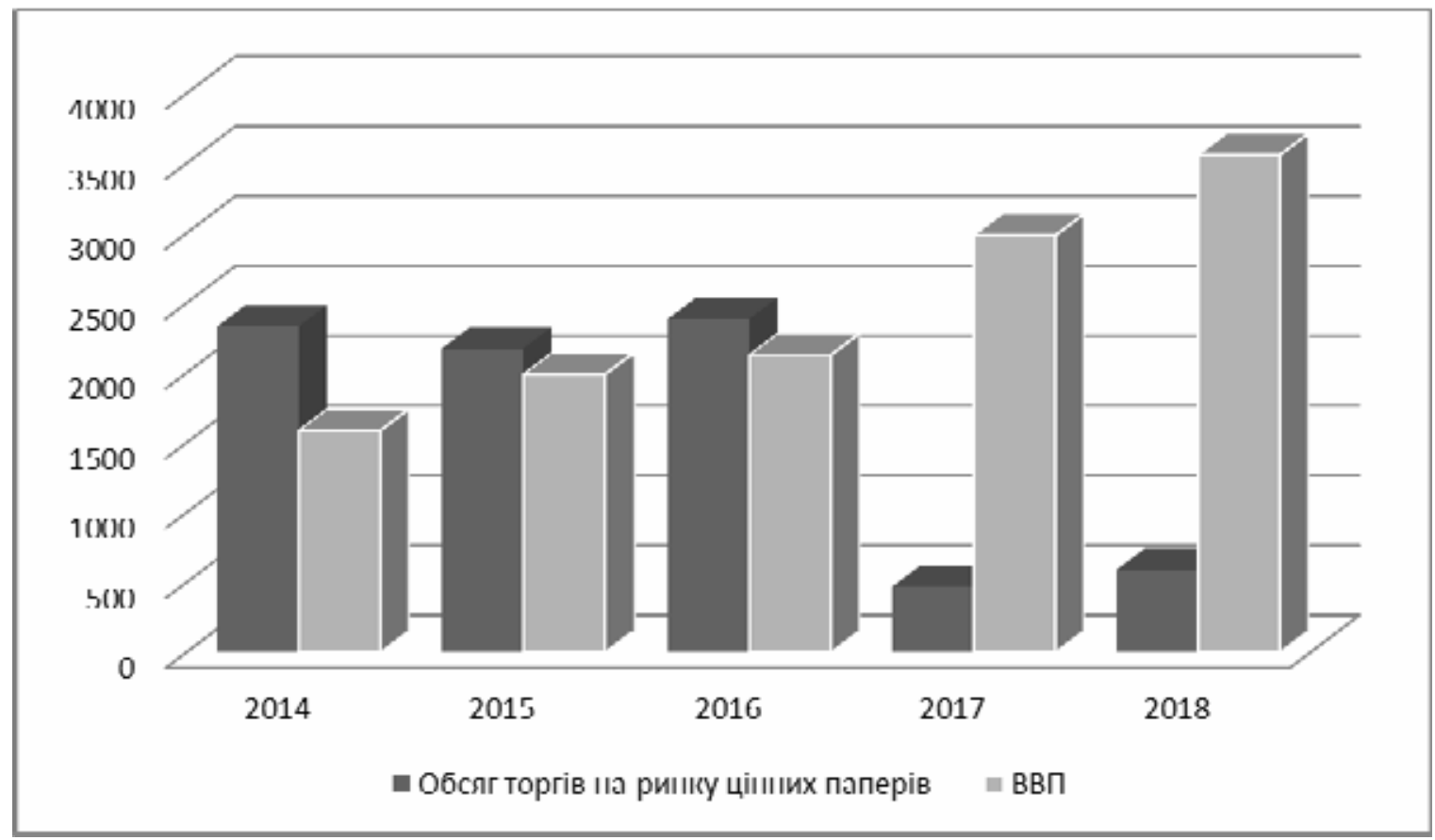

Рис. 2. Порівняльні дані обсягів торгів на ринку цінних паперів та ВВП в Україні у 2014-2018 рр., млрд. грн.

Примітка. Джерело [3] 
Хоча і в порівнянні з 2017 роком обсяг торгів збільшився, але порівнюючи з 2016 роком цей показник зменшився майже у 4 рази. Частково дане скорочення можна пояснити не врахуванням у розрахунках обсягу торгів депозитних сертифікатів Національного банку України починаючи з 2017 року. Проте таке зменшення обсягів торгів можна також пов'язати із впровадженням ряду законодавчих актів спрямованих на удосконалення регулювання та впровадження прозорості на ринку цінних паперів, таким чином відсіявши деяких недобросовісних учасників фондового ринку.

За результатами торгів на організованому ринку протягом січня-серпня 2019 року обсяг біржових контрактів 3 цінними паперами склав 205,75 млрд. грн. Протягом січня-серпня 2019 року порівняно 3 даними аналогічного періоду 2018 року обсяг біржових контрактів з цінними паперами на організаторах торгівлі збільшився на 17,63\% (січень-серпень 2018 року - 175 млрд. грн.) [3].

Незважаючи на різницю у стані українського біржового ринку у порівнянні із іншими біржами світу, все ж таки існують позитивні тенденції його подальшого розвитку та ряд проблем, без вирішення яких неможливе успішне виконання фондовим ринком покладених на нього функцій: залучення інвестицій та розподілу капіталу.

Після огляду сучасних тенденцій функціонування фондового ринку України ми виділили чотири найактуальніші проблеми його розвитку: законодавча неврегульованість корпоративного управління; проблема організації фондового ринку; недосконалість депозитарно-клірингової інфраструктури; несвоєчасність, необгрунтованість та часто недостовірність інформації про діяльність учасників фондового ринку України.

Першою проблемою $\epsilon$ законодавча неврегульованість питань корпоративного урядування в акціонерних товариствах. Повсякчас виявляються численні порушення прав акціонерів щодо розподілу додатково випущених акцій, щодо прав акціонерів в управлінні акціонерним товариством тощо. Об'єктивно корпоративне управління є безперервним процесом узгодження інтересів і подолання суперечностей, що виникають. Втім, ці процеси мають бути чітко регламентовані [4].

Друга проблема стосується організації фондового ринку України, а саме тривалості існування головного регулятора ринку цінних паперів - НКЦПФР. Комісія була створена тільки у 1995 році, а Українська біржа вже існувала з 1991 року. Це спричинило ситуацію існування ринку без регулятора протягом 4 років, що призвело до багатьох негативних наслідків. які все ще впливають на розвиток фондового ринку країни. Для прикладу, Комісія з цінних паперів та бірж у Польщі була створена одночасно із заснуванням Варшавської фондової біржі, що посприяло виходу фондового ринку країни на лідируючі позиції у Свропі.

Третьою гострою проблемою українського фондового ринку є формування депозитарно-клірингової інфраструктури. Українська депозитарна система на сьогодні не відповідає вимогам інвесторів та акціонерних товариств і практично не відповідає аналогічним системам розвинених країн. У останніх обслуговування $95 \%$ організованого ринку забезпечується центральними депозитаріями [10, с. 81].

Депозитарна система України абсолютно не відповідає сучасним вимогам ринку капіталів. Найбільше вона відстає в технологічному розвитку платіжної системи, таким чином відбувається гальмування обігу фінансових інструментів на українському ринку.

Шляхами вирішення трьох вищезгаданих проблем можуть бути наступні кроки.

Для вирішення першої проблеми, а саме врегулювання питань корпоративного управління в акціонерних товариствах, в першу чергу, необхідно забезпечити захист прав інвесторів. Це можливо зробити шляхом:

- по-перше, строгого дотримання законодавства, вимог регулятора та стандартів ділової етики з боку професійних учасників ринку цінних паперів;

- по-друге, врегулювання конфліктів інтересів, зокрема через розподіл повноважень на законодавчому рівні;

- по-третє, захисту інвестора від маніпулювань цінами на фондовому ринку (як було зауважено, законодавчо визначити види маніпулювань) та використання інсайдерської інформації [4].

Щодо розв'язання проблеми організації фондового ринку України, то можливості для формування ефективного регуляторного органу втрачені за ці роки можна відновити за рахунок якнайшвидшого впровадження необхідних законодавчих норм, розширення повноважень та приведення Комісії до вимог міжнародних стандартів.

Так тільки за 2018 рік Національною комісією з цінних паперів та фондового ринку було затверджено та зареєстровано в Міністерстві юстиції України 69 нормативно-правових актів, серед яких: 12 - регулюють нові правові відносини, 47 - вносять зміни до діючих нормативно-правових актів та 10 - про втрату чинності [8]. Враховуючи дані нормативно-правові акти, за висновком Комісії, можна вважати, що в Україні повністю сформована та функціонує інфраструктура фондового ринку. Також значний крок до вдосконалення НКЦПФР буде зроблено з прийняттям Закону України «Про внесення змін до деяких законодавчих актів України щодо захисту інвесторів від зловживань на ринках капіталу» на основі законопроекту від 04.07.2018. Зазначений законопроект передбачає посилення інституційної та фінансової спроможності Комісії з метою приведення повноважень та статусу вітчизняного регулятора фондового ринку у відповідності до найкращих світових стандартів, зокрема принципів Міжнародної організації комісій з цінних паперів (IOSCO) [8].

Після прийняття даного закону НКЦПФР стане самостійним та незалежним органом, який буде фінансуватися, в основному, за рахунок сплати внесків на регулювання учасниками фондового ринку коштів, а також коштів, що надходять від урядів іноземних держав, міжнародних організацій, донорських установ, а 
також інших джерел. Ще позитивним аспектом даного законопроекту є можливість створення правових умов для приєднання Комісії до Меморандуму IOSCO та забезпечення можливості здійснення міжнародного співробітництва.

Для вирішення третьої проблеми (формування депозитарно-клірингової інфраструктури) державою вже зроблені перші кроки. 30 вересня 2019 року в промислову експлуатацію введена нова IT-платформа Центрального депозитарію DEPEND Q, що призведе до якісних змін у роботі системи депозитарного обліку українського ринку цінних паперів. В нову систему було переведено інформацію про 3 млн рахунків, номінальна вартість яких складає 1,7 трлн грн. Нова платформа дозволяє депозитарним установам самим обирати альтернативне ПЗ для обслуговування клієнтів. Промисловий запуск нової ІТ-платформи є черговим кроком $з$ впровадження передових технологій в роботу депозитарної системи України та інтеграції в міжнародні ринки капіталу [2].

Але, незважаючи на проблеми вказані вище, ми вважаємо, що четвертою і найгострішою проблемою фондового ринку в сучасному контексті $є$ несвоєчасність, необгрунтованість та часто недостовірність інформації про діяльність учасників фондового ринку України.

Інформація та інформаційні технології мають суттєвий вплив на сучасне життя, і в тому числі сильно вдосконалюють процес комунікації, бізнес, управління на освіту. А враховуючи біржову діяльність, то сучасні інформаційні технології також впливають на продуктивність світового фондового ринку.

Інформаційні технології включають збір, організацію, зберігання, та публікацію даних, які у свою чергу включають аудіо, відео, текст чи фігури, які передбачають використання комп’ютерних інструментів та телекомунікацію [5].

Беручи до уваги різноманітні визначення і широке використання інформаційних технологій (IT) у різних сферах життя людини, розвиток інформаційних технологій є необхідним для економічного зростання $\mathrm{i}$ розвиток країн через декілька причин. По-перше: такі технології підвищують швидкість передачі даних, і в такий спосіб інформація надходить до більшої кількості осіб. По-друге: IT скорочує витрати на виробництво, оскільки вони надають доступ до зібраних знань за мінімальні витрати. По-третє: IT долає перешкоди часу і простору, і як результат, інформація між покупцями і продавцями передається набагато швидше. I остання причина:інформаційні технології покращують прозорість ринку, за якою слідує збільшення попиту окремих осіб на легкий доступ до необхідних даних [9].

Професори Луїзіанського університету також вважають, що є багато причин вважати, що інвестиції країни у покращення інформаційно-комунікаційних технологій може призвести до економічного зростання. Вони стверджують, що покращення доступу до сучасної телекомунікації може скоротити витрати на передачу інформації, і також це зробить інформацію доступнішою для тих, хто приймає рішення, і тому окремі учасники, так само як і організатори ринку, можуть робити більш зважені рішення, що призведе до збільшення продуктивності [1].

Враховуючи вищесказане, можна стверджувати, що проблема вдосконалення механізмів інформаційного забезпечення учасників фондового ринку має бути основною, а також такою, яка потребує першочергового вирішення.

Важливо зазначити, що інформація, яка надходить на ринок від емітентів цінних паперів може значно вплинути на їх ринкову вартість. Основним видом інформації, яка розкривається емітентами є їхня звітність, але велика кількість аналітиків вважає, що на практиці ця інформація, зазвичай, не відповідає дійсності, оскільки емітенти прагнуть показати результати своєї роботи для інвесторів із кращої сторони.

Згідно 3 ч. 1 ст. 39 Закону «Про цінні папери та фондовий ринок» регульована інформація розкривається у встановленому Національною комісією з цінних паперів та фондового ринку порядку шляхом іiі розміщення в загальнодоступній інформаційній базі даних Національної комісії з цінних паперів та фондового ринку про ринок цінних паперів або через особу, яка провадить діяльність з оприлюднення регульованої інформації від імені учасників фондового ринку. Якщо інше не передбачено законодавством, регульована інформація також розкривається шляхом:

1) розміщення іiі на власному веб-сайті учасника фондового ринку;

2) подання іiї до Національної комісії з цінних паперів та фондового ринку [6].

Відповідно до недавніх змін до ЗУ «Про цінні папери та фондовий ринок», 31 січня 2019 року для приватних акціонерних товариств будуть існувати тільки два обов'язкових способи розкриття інформації на фондовому ринку:публікація на власному веб-сайті та подання до НКЦПФР. А для публічних акціонерних товариств і банків розкриття інформації повинно відбуватися трьома способами - подання до НКЦПФР, оприлюднення на власному веб-сайті, поширення інформації у загальнодоступній інформаційній базі даних про ринок цінних паперів (www.stockmarket.gov.ua) або через інформаційного агента з розкриття інформації.

Ще 2018 року найбільш поширеним способом розповсюдження інформації про емітентів було іiі розміщення у офіційних періодичних виданнях Національної Комісії з цінних паперів та фондового ринку: бюлетеня «Цінні папери України», газети «Цінні папери України», журналу «Ринок цінних паперів України», де можна було знайти найактуальніші дані про учасників фондового ринку. Але зрозуміло, що через специфіку, і певний час необхідний для друку даних видань таку інформацію не можна було вважати актуальною, а тим більше використати іiі для інвестиційної діяльності. Але з 1 січня 2019 року таку застарілу, на наш погляд, норму було скасовано, що свідчить про позитивні зміни у напрямі діджитилізації фондового ринку України. 
Ще одним кроком до полегшення отримання актуальної інформації своєчасно є запровадження НКЦПФР обов'язкової вимоги до всіх акціонерних товариств, незалежно від форми, мати власний веб-сайт у мережі Інтернет.

Важливим шляхом вдосконалення інформаційного забезпечення учасників фондового ринку України $\epsilon$ також створення нового виду діяльності на фондовому ринку. Таким видом діяльності $є$ агент 3 розкриття інформації. Враховуючи даний факт, Загальнодоступна інформаційна база даних НКЦПФР, яка висвітлює інформацію про ринок цінних паперів (www.stockmarket.gov.ua) втратить свою монополію. Такі агенти зможуть не тільки оприлюднювати регульовану інформацію від імені емітентів, але і також розповсюджувати в безперервному режимі консолідовану інформацію про цінні папери. Це дозволить інвесторам (інституційним або індивідуальним) отримувати вчасно адекватну інформацію щодо емітентів та їхні цінні папери, і приймати обгрунтовані рішення щодо своїх подальших інвестицій.

Оскільки такі агенти як юридичні особи повинні мати певний набір правил та технічних засобів узгоджених із НКЦПФР, які повинні забезпечити оприлюднення інформації у режимі, що максимально наближений до реального часу, то це покращить своєчасність інформації отриманої інвесторами. А, крім цього, така інформація повинна стати безкоштовною як для юридичних, так і для фізичних осіб, що дозволяє покращити інформативну забезпеченість простого населення як потенційного інвестора на ринку цінних паперів України.

Всі юридичні особи, які мають намір здійснювати таку інформаційну діяльність повинні пройти авторизацію від НКЦПФР. Агентства з надання інформаційних послуг на фондовому ринку розпочали свою діяльність $з 1$ січня 2019 року. Але, на жаль, ефективність та рівень впливу на покращення інформаційного забезпечення фондового ринку України ще важко оцінити.

Висновки. Оскільки фондовий ринок в Україні знаходиться все ще на етапі становлення, і ще не існує сформованої інституційної поведінки учасників ринку, необхідно посилити нормативно-правове регулювання державою його діяльності. Основним регулюючим органом фондового ринку країни є комісія з цінних паперів та фондового ринку. Розширення ії повноважень, а також реалізація всіх її функцій відповідно до міжнародних стандартів дозволить сформувати основу для подальшого розвитку ринку цінних паперів України. На сучасному етапі розвитку однією 3 найгостріших $\epsilon$ проблема інформаційного забезпечення учасників фондового ринку, оскільки іiі вирішення може значно пожвавити фондовий ринок України за рахунок збільшення інвестицій простого населення, а також іноземних інвесторів, для яких систематична, своєчасна та достовірна інформація є основою прийняття інвестиційних рішень.

\section{Література.}

1. Вплив інформаційно-комунікаційних технологій на капіталізацію біржового ринку: аналіз панельних даних [Електронний ресурс] / С.Лі, М. Альфорд, Д. Крессон, Л. Гарднер // Бізнес та економічні дослідження. 2017. Режим доступу

https://pdfs.semanticscholar.org/0b99/9f4027f32cf556fa749784bc06808b9457eb.pdf.

до pecypcy:

2. Головні новини [Електронний ресурс] // Національна комісія з цінних паперів та фондового ринку. 2019. - Режим доступу до ресурсу: https://www.nssmc.gov.ua/.

3. Інформаційна довідка щодо розвитку фондового ринку України протягом січня-серпня 2019 року [Електронний ресурс] // Національна комісія з цінних паперів та фондового ринку. - 2019. - Режим доступу до pecypcy: http://www.ssmsc.gov.ua/fund/analytics.

4. Колупаєв Ю. Б. Обгрунтування напрямку перспективного розвитку фондового ринку України / Ю. Б. Колупаєв, С. С. Залюбовська, М. А. Яковенко. // Ефективна економіка. - 2018. - №8.

5. Ньєбель Т. IT та економічне зростання - порівняння розвитку, розвинуті країни та ті, що розвиваються [Електронний ресурс] / Т. Ньєбель // IARIW 33rd General Conference. - 2014. - Режим доступу до pecypcy: http://www.iariw.org/papers/2014/NiebelPaper.pdf.

6. Про цінні папери і фондовий ринок: Закон України від 23.02.2006 № 3480-IV (зі змінами i доповненням) [Електронний ресурс] / Верховна Рада України. - Режим доступу:http://zakon3.rada.gov.ua/laws/show/3480-15.

7. Річний звіт [Електронний ресурс] // Світова федерація бірж. - 2018. - Режим доступу до ресурсу: https://www.world-exchanges.org/home/index.php/ statistics/monthly-reports.

8. Річний звіт НКЦПФР за 2018 рік [Електронний ресурс]. - 2019. - Режим доступу до ресурсу: https://www.nssmc.gov.ua/documents/rtchniy-zvt-nktspfr-za-2018-rk/.

9. Сепегдовст Г. Вплив інформаційно-комунікаційних технологій та фінансового розвитку на економічне зростання країн ОПЕК [Електронний ресурс] / Г. Сепегдовст // Журнал суспільних наук Касетсартського університету. - $2018.2-1$ Режим доступу до ресурсу: https://www.sciencedirect.com/science/article/pii/S2452315117303612.

10. Фондовий ринок: підручник / [О.М. Мозговий, А.Ф. Баторшина, О.Г. Величко, Т.О. Фролова та ін.]. - K. : КНЕУ. - 2013. - 537 c.

\section{References.}

1. Lee, S. Alford, M. Cresson, J. and Gardner, L. (2017), "The Effects of Information Communication Technology on Stock Market Capitalization: A Panel Data Analysis", Business and Economic Research, Vol. 7, No. 1, 
available at: https://pdfs.semanticscholar.org/0b99/9f4027f32cf556fa749784bc06808b9457eb.pdf (Accessed 12 Nov 2019).

2. National commission of securities and Stock Exchange (2019), "The main news", available at: https://www.nssmc.gov.ua/ (Accessed 12 Nov 2019).

3. National commission of Securities and Stock Market (2019), "Information about development of Stock market during January - August 2019”, available at: http://www.ssmsc.gov.ua/fund/analytics (Accessed 12 Nov 2019 ).

4. Kolupayev, Yu. Zalyubovska, S. and Yakovenko, M. (2018), "Substantination of directions of perspective development of the stock market of Ukraine", Effective economy, vol. 8, available at: http://www.economy.nayka.com.ua/?op=1\&z=6570 (Accessed 12 Nov 2019).

5. Niebel, T (2014), "ICT and Economic Growth - Comparing Developing, Emerging and Developed Countries", Paper Prepared for the IARIW 33rd General Conference, available at: http://www.iariw.org/papers/2014/NiebelPaper.pdf (Accessed 12 Nov 2019).

6. The Verkhovna Rada of Ukraine (2006), The Law of Ukraine "On Securities and Stock Market", available at: http://zakon3.rada.gov.ua/laws/show/3480-15 (Accessed 12 Nov 2018).

7. World federation of exchange. (2018) Available at: https://www.world-exchanges.org/home/index.php/ statistics/monthly-reports (Accessed 12 Nov 2019).

8. National commission of Securities and Stock Market (2019), "Annual Report on 2018", available at: https://www.nssmc.gov.ua/documents/rtchniy-zvt-nktspfr-za-2018-rk/ (Accessed 12 Nov 2019).

9. Sepehrdoust, H. (2018), "Impact on information and communication technology and financial development on economic growth of OPEC developing economies", Kasetsart Jornal of Social Sciences, available at: https://www.sciencedirect.com/science/article/pii/S2452315117303612 (Accessed 12 Nov 2019).

10. Mozhovyy, O.M. Batorshyna, A.F. Velychko, O.H and Frolova, T.O. (2013), Fondovyy rynok [Stock market], KNEU, Kyiv, Ukraine. 